Piotr Kamiński $i^{1,2}$, Agnieszka Wiśniewska², Leszek Jerzak ${ }^{3}$, Paweł Żuchowski ${ }^{4}$, Sławomir Jeka ${ }^{5}$, Brendan P. Kavanagh ${ }^{6}$, Wojciech Kozera ${ }^{7}$, Alina Woźniak ${ }^{8}$

${ }^{1}$ Nicolaus Copernicus University, Collegium Medicum, Department of Medical Biology and Biochemistry, Department of Ecology and Environmental Protection, Bydgoszcz, Poland

2University of Zielona Góra, Faculty of Biological Sciences, Department of Biotechnology, Zielona Góra, Poland

3University of Zielona Góra, Faculty of Biological Sciences, Department of Nature Protection, Zielona Góra, Poland

${ }^{4}$ University Hospital No. 2, Independent Section of Scientific Research Coordination and Didactic Activity, Bydgoszcz, Poland

${ }^{5}$ Nicolaus Copernicus University, Collegium Medicum, Department of Rheumatology and Connective Tissue Diseases, Bydgoszcz, Poland

${ }^{6} \mathrm{RCSI}$ Biology, Royal College of Surgeons in Ireland, Dublin, Ireland

${ }^{7}$ University of Technology and Life Sciences, Faculty of Agriculture and Biotechnology, Department of Agricultural Chemistry, Bydgoszcz,

Poland

${ }^{8}$ Nicolaus Copernicus University, Collegium Medicum, Department of Medical Biology and Biochemistry, Bydgoszcz, Poland

\title{
Ecophysiological determinants of the human skeletal system
}

\section{Corresponding author:}

Piotr Kamiński, Nicolaus Copernicus University, Collegium Medicum, Department of Medical Biology, Department of Ecology and Environmental Protection, M. Skłodowskiej-Curie St. 9, PL 85-094 Bydgoszcz, Poland, e-mail: piotr.kaminski@cm.umk.pl
Medical Research Journal 2018; Volume 3, Number 2, 47-54 10.5603/MRJ.2018.0009

Copyright (C) 2018 Via Medica ISSN 2451-2591

\begin{abstract}
This review assessed relationships between external factors and the level of joint pathology (hip, knee, ankle, elbow, shoulder, hands and feet) in humans with dysplastic arthritis, psoriatic arthritis, rheumatoid arthritis, Sjögren's syndrome, systemic lupus erythematosus, systemic sclerosis, degenerative joint disease, ankylosing spondylitis, osteoporosis, osteomalacia and gout. The accumulation of physiologically different chemical elements in different types of bones in humans of different ages allows for a more accurate assessment of the causal quoted response from parallel biochemical systems. These allow a better understanding of the link between exposure arising from smoking, alcohol, drugs, diseases, heredity, effects of amalgam dental fillings, diet, food preferences, chemical elements, occupational and environmental exposure to toxicants, lipoperoxidation and pro-antioxidant reactions.

Physiology of the osteoarticular system determines what is responsible for bone and long-term body accumulation of toxic metals, which may be involved in the pathogenesis of bone diseases. While relationships between stressors, antioxidant system and bone condition predict potential risks in certain abnormalities and change oxidative stress. Elemental instability in the environment combined with salinity, acidity, redox potential and local changes in hydrochemical balance, enhances adverse effects. Processes of remodeling and bone mineralization continue throughout life and therefore may be a determinant of long-term accumulation of toxicants.

Environmental issues affecting bioaccumulation of chemical elements in the osteoarticular system in humans is poorly understood. Alloplastic procedures, including the need for prostheses, supplemented by image layouts oxidative enzyme activities, as well as lipoperoxidation and the level of stress proteins, give a complete picture of skeletal response to external stressors. Simultaneously, the analysis of the impact of stressors on bones allows a more accurate tracing of causal quoted responses from parallel reactions. They have a direct relationship with stressors and affect the nature and degree of responses and defense capabilities. Thus they have a role in the diagnosis of diseases of the skeletal system.
\end{abstract}

Key words: osteoarticular system; bone tissue; antioxidant enzymes; toxic metals; environmental stress; total hip replacement

Med Res J 2018; 3 (2): 47-54

\section{Introduction}

Key features of the skeleton are conditioned by the processes of bone resorption and formation, which can be disrupted by hormonal changes, age-related factors, changes in physical activity, stimulants, etc. [1-2]. There are few studies concerned with the analysis of the concentrations of chemical elements in bones. This is due to difficulties in the acquisition of suitable test material. Cash skeletal element is associated with hospitalization, where most analyzed bones are collected at the time of joint replacement procedures or biopsy. The elemental 
composition of bones is influenced by gender, age, metabolic activity and the impact of environmental factors [3-6]. Studies show a strong influence of the environment on the elemental composition of skeletal system [7-8]. Changes in the concentration of chemical elements in bones may also be due to the presence of different levels of elements in soil and their secondary migration to bones. This process is also a result of the emission of chemical elements to the environment [5]. Disorders of mineral metabolism often cause osteoporosis. An important criterion for evaluating the effectiveness of osteoporosis treatment is to assess bone mineral density (BMD); [9-11] and biochemical markers of bone turnover (12). In addition, metabolic disorders associated with thyroid disease, kidney disease, pancreatitis or diabetes, can lead to secondary osteoporosis [13-16].

Degenerative joint diseases occur due to restricted physical activity, especially affecting hip and knee joints. Degenerative changes apply to all structures of the joint, i.e. articular cartilage, joint capsule, synovium, and periarticular structures. A variety of factors are involved in the development of basic changes including biological, biomechanical, metabolic, inflammatory and immunological factors [17-18]. This leads to disruption of metabolic processes of the body and, finally, to the induction of reactive oxygen species generation (ROS). A number of studies describe the activity of antioxidant enzymes (superoxide dismutase SOD, catalase CAT, glutathione $\mathrm{GSH}$, glutathione-peroxidase GPx, glutathione-reductase GR), which are the body's protective barrier against oxidative damage. These are highly specialized enzymes related to antioxidant activity [19-20]. The antioxidant barrier of the body is further enhanced by the presence of acute phase proteins, e.g. ceruloplasmin $\mathrm{CP}$, ferritin FRT, and haptoglobin HPT, occurring mainly in the plasma. Their protective action is in the chelation of metal ions that are responsible for induction of free radicals [21]. Experiments dealing with relationships between the level of antioxidant enzymes activity, which are the body's antioxidant barrier, and the degree of physical activity, have been completed. The studies included patients with short-term and long-term hypokinesia resulting in impaired physiological and biochemical reactions of the body leading to degenerative arthritis and bone metabolism disturbances. However, these studies provide conflicting results and fail to identify a clear relationship between the condition of the antioxidant system and immobilization of the patient [22-25].

Some studies demonstrated a positive effect of melatonin and copper supplementation on antioxidant enzymes [20, 25]. Reactive oxygen species initiate lipid peroxidation, which results in increased levels of malondialdehyde (MDA) in the body. However, MDA has cytotoxic and mutagenic effect and may contribute to carcinogenesis [26]. Studies have shown different results on the regularity of the action of the antioxidant system in the process of lipid peroxidation [27-28, 22-24]. Nonetheless, it was found that an imbalance in the body's oxidation and antioxidation system affected bone mineral density [29].

The activity of oxidative enzyme systems and the intensity of lipoperoxidation and protein levels during stress can give a complete picture of the body's response to different environmental stressors. Therefore, in future studies, spectroscopy measurement of fluorescence should be extended to include advanced glycation end products (AGEs); [30]. Simultaneously, analysis of the degree of accumulation of chemical elements in various types of bones in men and women of different ages at the same time can allow for a more accurate trancing of causal effect with reactions from biochemical systems. Furthermore, the impact of heavy metals on the skeletal system is multidirectional and the impairment of the osteoarticular system is the best known long-term effect [8, 21, 19]. Understanding of these conditions will contribute to a better understanding of the link between the exposure arising from smoking, the effects of amalgam dental fillings, diet and food preferences and the level of chemical elements, lipoperoxidation processes and pro-antioxidant reactions on the skeletal system.

For this survey we incorporated different stress factors (tobacco, alcohol, dental amalgams, diet, disease, hereditary conditions, occupational and environmental exposure to toxic agents), which in turn, may have a direct relationships with the level of chemical elements in the body. In this study we make relevant comparisons between the groups of external factors in the development of defense capabilities of the human. These results can be used in the diagnosis of diseases of the skeletal system, mainly rheumatoid arthritis, osteoporosis, osteomalacia, and arthritis). In addition, we show that destabilization of the economy of elemental contamination of the environment can trigger the response of the skeletal system to environmental stressors. Other studies have shown a negative impact of various elements of chemical reactions taking place in the human bone tissue [5-6, 11, 31-33]. Those studies have also established a causal and consecutive link between the concentration of chemical elements and the level of activity of antioxidant systems of the cartilage and bone, in the course of bones and joints diseases [3, 5, 31-32].

Degenerative arthritis and osteopathy of joints and changes in the nature of osteoporosis usually occur in older individuals, often resulting in alloplastic procedures, including the need for prostheses. Thus, the aim of this review is to analyze how supplemented image layouts, oxidative enzyme activities, a knowledge of lipoperoxidation intensity and the level of stress proteins, 
can give a complete picture of the response of the skeletal system to external stressors. Simultaneously, we analyzed the extent of accumulation of physiologically different elements in various types of bones in humans of different ages, which enables a more accurate trace causal quoted response from the parallel biochemical systems to be assessed. These studies make possible to assess whether in humans the link exists between the exposure arising from smoking, the effects of amalgam dental fillings, as well as the diet and food preferences, and the level of chemical elements, lipoperoxidation processes and pro-antioxidant reactions. They are important for a better evaluation of patients, taking into account the possible stress factors (tobacco, alcohol, dental amalgams, diet, disease, hereditary, occupational and environmental exposure to toxic agents). They highlight a direct relationship between the level of chemical elements in bones and the nature and degree of response to these external stressors. They also highlight the importance of external factors in the development of defense capabilities of humans. These analyzes can also contribute to the diagnosis of musculoskeletal disorders (such as rheumatoid arthritis, osteoporosis, osteomalacia or degenerative diseases and arthritis).

\section{External and pathophysiological changes in the osteoarticular system}

Diseases of the osteoarticular system are a major problem in modern medicine, since they affect millions of women and men, and their treatment is problematic from a medical and economic point of view [34-35]. The osteoarticular system is subjected to a variety of factors that affect normal functioning. The complexity of pathophysiological conditions of this system manifests itself in many systemic and multi-organ changes.

Rheumatoid arthritis (RA) is dominated by inflammatory reactions of an autoimmune multiorgan nature, which often takeover as in other connective tissue diseases. The changes in structure of the joint in genetically susceptible individuals, as a result of an abnormal immune response to the unknown antigen, result in impaired joint mobility due to synovial inflammation affecting the joints symmetrically. The initial symptoms are pain and swelling, progressing to the irreversible loss of joint function. This results in progressive disability. The etiology of the disease is not fully understood, but some of the factors initiating the inflammatory process are chemicals, viruses, bacteria, immune disorders and injuries of joints [36-40]. On the other hand, osteoarthritis (OA) is a chronic disease of musculoskeletal system, most often occurring in the most loaded joints: the spine, hip and knee joints. Degenerative changes occur in all structures of the joint. Biological, biome- chanical, metabolic, immunological and inflammatory reactions may be involved in the development of basic changes [17-18]. OA often develops in obese patients with type 2 of diabetes [14]. Dobrogowski et al. [40] reported that the direct cause of osteoarthritis is irregularity in the continuity of joint cartilage and subchondral abnormalities in the bone [40] and the progressive degradation of articular cartilage and periarticular bone areas is a result of these pathologies. The characteristic radiographic bone spurs (osteophytes) with narrowing of the articular gap are observed. Ultimately, this leads to deformation of the joint, pain, limitation of movement and joint stiffness [40-44].

Osteoporosis affects people of all age groups, though there are a number of risk factors (genetics, race, advanced age, female gender, family predisposition, low physical activity, a diet low in calcium and vitamin D, medications and stimulants). It may also be affected by thyroid, kidney disease, pancreatitis and diabetes [13-16]. Susceptibility to bone fractures due to reduced bone mass and changes in the bone micro-architecture is a characteristic clinical symptom of osteoporosis. An important criterion for assessing the effectiveness of osteoporosis treatment is the assessment of bone mineral density (BMD) and biochemical markers of bone turnover [10-11, 45-46]. These studies found radiological subperiosteal fractures, alterations in trabecular bone, thinning of bone cortex, and increased transparency of bones affected by osteoporosis. Visible radiographic changes occur in the late period, when bone loss is greater than $30 \%$ [47]. Progressive disease leads to disability of the patient [41, 48-52]. This is particularly true for fractures of the femoral neck, for which few patients return to full fitness. These fractures are typically characterized by a high percentage of mortality [53]. For this reason, examining bone tissue from patients undergoing hip replacement is of great value because it is one of the most serious sites of fragile fractures. Similar changes accompany osteomalacia (rickets in adults), where an additional risk factors include vitamin $D$ deficiency in the diet or due to lack of sun exposure, and advanced age. Pathophysiological changes in osteomalacia are associated with impaired mineralization due to insufficient accumulation of calcium in bones. Histologically, bone trabeculae have the correct number and size, but are poorly calcified [54-56].

Gout is an arthritis caused by the accumulation of sodium urate crystals in synovial fluid, resulting in phagocytosis by neutrophils and activation of inflammatory mechanisms, leading to the formation of deposits in joint tissues and other organs (kidney, skin). Hyperuricemia and elevated level of uric acid in the blood, which may be asymptomatic, yet contribute to attacks of acute arthritis, trophic appearance, and pathological 
changes in the kidneys, joints and bone [57-58]. These symptoms are caused by tissue injury due to the precipitation of sodium urate crystals or hyperuricemia. The latter may be initiated by stress, hunger, alcohol intake and metabolic acidosis [37, 59-60]. Thus the range of environmental conditions contributing to diseases of the osteoarticular system is very wide. Our own study [33] investigated the link between environmental factors and the reactions of oxidative enzyme systems in the course of diseases of bone and joints.

\section{Bone tissue and its metabolism under environmental stress}

A normal healthy osteoarticular joint system has two essential functions for the body: mechanical and metabolic. Bone and organs are protected by muscles, attached to the bone scaffolds to provide movement [2]. The role of the skeletal system in metabolism involves the production of blood cells, the storage of calcium, magnesium and phosphorus, and also the maintenance of the correct electrolyte balance. Trabecular bone and cortical bone are sensitive to the effects of xenobiotics and osteotropic hormones. This is due to the high metabolic activity of spongy bone. The response of bones to the internal factors (hormones, vitamins, IL-1, PGE2) and xenobiotics is expressed through bone remodeling and the process of carcinogenesis [2, 14, 61]. Exposure to heavy metals is a major risk factor influencing the bone tissue. Substances such as lead, cadmium, fluoride, aluminum, vinyl chloride, and carbon disulfide have negative effects on bone and joints. These substances are widely used in industry and thus have universal access to human bones.

Bones are the main site of lead accumulation through the life span. Lead toxicity for the osteoarticular system is dependent on the age of the individual and dose received. Lead may be a potential factor for osteoporosis, affecting osteoblasts and osteoclasts both directly and indirectly $[8,56]$. Lead can also block calcium channels competing with calcium ions [8]. However, the effects of lead on bone mineral density, are disputed in some studies [62]. No relationship between the presence of $\mathrm{Pb}$ and BMD (bone mineral density) in tibia and patella was found. In addition, cadmium, commonly found in the environment with lead, is a further source of contamination, hazardous to health, hence there have been numerous studies on its effects on the skeletal system. Cadmium causes demineralization, osteomalacia, osteoporosis and deformation of bones. Individuals particularly vulnerable to the adverse effects of cadmium on the bones include the elderly and women during and after menopause [63-67]. Cadmium interferes with absorption and incorporation of calcium, which is an essential component of bone mineral con- tent. Affected individuals often present hypocalcemia, because cadmium causes increased excretion of calcium in the urine, and inhibits the biosynthesis of calcitriol indirectly by inhibiting the absorption of calcium in the intestine $[56,63,67,68]$. Although not directly, cadmium generates free radicals, which is a source of exposure of cells to oxidative stress [69]. Antioxidants affect the body by displacement (replacement) of metal ions necessary for the functioning of antioxidant enzymes with $\mathrm{Cd}$ [70]. Molecular and cellular mechanisms of Cd toxicity are complex and still under investigation.

The bone and joint osteovascular system has a role in aluminum accumulation [71-74]. This element, particularly in its ionic form in the environment, causes osteomalacia. Also chlorides cause decalcification of the bones of extremities (acrosteolysis) in people exposed continuously [56]. In addition, carbon disulfide is known to interfere with bone mineralization [56-75].

Osteoporosis can be caused by chronic exposure of bone to corticosteroids, thyroid hormones, anticonvulsants and anti-thrombotics, e.g. heparin, and stimulants [56]. Bones are a key accumulation site of radioactive isotopes of strontium 90 and 226. Inserting $90 \mathrm{Sr}$ into bones causes demineralization, while 226Ra causes bone damage and contributes to the development of osteosarcoma $[56,76,77]$. Smoking also affects bone tissue, especially in postmenopausal women. Smoking causes weakening of the function and interaction of calcium containing compounds- hydroxyapatites and contributes to the loss of bone mass [32]. Coffee consumption may cause a reduction in bone density [78] and influence on bone metabolism. Diabetes results in an increased risk of bone fractures [79]. Changes in the osteoarticular system can also be caused by mechanical factors in the environment (vibration, shock, stroke). Long-term high-frequency vibrations result in bone ossification abnormalities and deformities of the articular surfaces [31]. In a study by [33] the analysis of exposure to harmful external factors was based on patient surveys. The patients answered questions about lifestyle: physical activity, diet, addiction, economic status. The questionnaire also included questions about disease, including a history of medication use that may also affect bone and joints. This study concluded that there is a relationship between the degree of impact of external factors and the condition of the skeletal system and the state of bone tissue.

\section{Bone tissue in the instability of elemental management in the environment}

We found several studies evaluating the influence of different external factors on the condition of the osteoarticular system. One of the external factors conditioning 
the status of osteoarticular system is smoking, which has an effect that weakens the function of calcium and its action in the bones, which contributes to the loss of bone mass. At the same time, smoking activates other accompanying factors and activates a similar activity [32 Sirola et al. 2003, 15 Chernyshowa et al. 2008)]. However, no relationship between the presence of lead and the rate of bone mineral density was found [62]. On the other hand, cadmium from smoking has just another action as a result of burning only one cigarette, $20 \mu \mathrm{g}$ of toxic $\mathrm{Cd}$ is released into the body, which acts destructively on the structure of bones and joints [63 Alfvén et al. 2002]._Cadmium is a widespread environmental pollutant, hazardous to health and numerous studies on the effect of cadmium on the human osteoarticular system and human bones have been conducted. Cadmium toxicity is the cause of demineralization, osteomalacia and osteoporosis of bones [67 Jakubowski et al. 1995, 63 Alfvén et al. 2002, 66 Nyhall-Wahlin et al. 2009]. Individuals particularly vulnerable to the adverse effects of cadmium include post-menopausal women [64 Lyn 2003, 65 Åkesson et al. 2006]. Molecular and cellular mechanisms of toxicity of $\mathrm{Cd}$ are complicated and are still under research. Cadmium generates free radicals, although not directly and is the source of exposure of cells to oxidative stress. This is the result of the inhibition of antioxidants by the displacement of metal ions by $\mathrm{Cd}$. This inhibition is known to affect the normal functioning of antioxidant enzymes [69-70].

Approximately $10 \%$ of bone mass is exchanged per year in a healthy person [80]. In addition, the physiological reduction of bone mass occurs in people aged 35-40 years [80]. For these reasons bone is a good biomarker of long-term accumulation of chemical elements due to this slow turnover. The elements within the bone tissue include $\mathrm{Ba}, \mathrm{Ca}, \mathrm{Cu}, \mathrm{Fe}, \mathrm{K}, \mathrm{Li}, \mathrm{Mg}, \mathrm{Na}, \mathrm{P}, \mathrm{S}, \mathrm{Sr}$, and $\mathrm{Zn}$. The bone tissue stores calcium, copper, iron, lead, cadmium [4, 6, 81-82]. Up to $99 \%$ of total body calcium is found in the bones. It is present in the bone tissue primarily as an insoluble form of hydroxyapatite crystals. That part of the calcium load, which can easily penetrate into the body fluid is small.

The second element in terms of the percentage in bones is phosphorus, occurring in the form of insoluble calcium phosphate salts [31, 83]. Bone tissue readily absorbs toxic elements, mainly cadmium, lead, radium, strontium and plutonium, that could potentially be a significant factor in the pathogenesis of diseases of bones and joints [5, 31]. The levels of these elements in the bones are influenced by age and gender. Studies by Kwapulinski et al. [5] and Zaichick et al. [6] show that the rib bones of healthy women have a greater content of $\mathrm{Ca}, \mathrm{Mg}, \mathrm{Na}, \mathrm{P}$ and $\mathrm{Sr}$, and a lower concentration of $\mathrm{Fe}$, and $\mathrm{Pb}$ compared to the rib bones of men. The concentration of $\mathrm{Ca}, \mathrm{Mg}$ and $\mathrm{P}$ in bones tends to decrease with age, regardless of sex, whilst the concentration of Fe increases with age in men's ribs [6]. A strong relationship was identified between the concentration of $\mathrm{Mn}$ and $\mathrm{Cd}$, and $\mathrm{Pb}$ and $\mathrm{Fe}$ in the femoral bone of coal mine, steel mills and gas station workers [8]. The level of chemical elements in bones, which depends on the impact of environmental factors, age, sex, and metabolic activity has been reported as early as in 1987 [3]. Changes in the concentration of chemical elements in the bones can also results from a variation of levels in soils leading to secondary migration to the bones. Soil contamination results from the emission of chemical elements to the environment by industrial activity [5]. It is important for bone tissue to maintain mineral homeostasis. The disruption of mineral homeostasis can lead to bone metabolic diseases, especially osteoporosis. Therefore, it is important to determine the level of these elements in bones [6, 11]. Wiśniewska [33] analyzed the concentration of $\mathrm{Ca}, \mathrm{Cd}, \mathrm{Cu}, \mathrm{Fe}, \mathrm{K}$, $\mathrm{Mg}, \mathrm{Na}, \mathrm{P}, \mathrm{Pb}, \mathrm{S}, \mathrm{Sr}$, and $\mathrm{Zn}$ in the bone samples taken from patients after joint replacement. She investigated whether there was a positive correlation between the content of elements in the bones (especially $\mathrm{Cd}$ and $\mathrm{Pb}$ ) and the condition of bone tissue. The data suggest that these relationships do exist. Other studies found relationships between the concentration of elements in the bones and external factors (diet, alcohol, physical activity). We report on the impact of environmental stressors on the level of chemical elements in the bones and the responses of bone to these elements [33].

\section{Pro-antioxidant system of the body and the condition of bone tissue}

It is estimated that up to $5 \%$ of oxygen absorbed by the body can be converted to reactive oxygen species. ROS can be affected by exogenous and endogenous factors. Exogenous factors which contribute to the formation of ROS include air pollution, tobacco smoke, ultraviolet light and ionizing radiation. However, the primary source is from the inner mitochondrial respiratory chain, carried out by the oxidoreductase reactions and the reactions of cytochrome P-450 [84-85]. High activity of ROS causes degenerative processes in cells, including lipid peroxidation, protein oxidation, and nucleic acid structure disorders [86, 87]. Aerobic processes have evolved protective mechanisms to maintain the physiological level of ROS. Specialized oxidative enzymes control on the level of antioxidants. They reduce the production of reactive oxygen species [19, 88-89]. Superoxide dismutase catalyzes the reactions in which the basic anions produce hydrogen peroxides and superoxide. Catalase is responsible for the neutralization of hydrogen peroxide by conversion to water and oxygen $[19,90]$. A positive effect of supplementation with 
copper antioxidant enzymes (CAT, GPx) in patients with osteoarthritis is known. This may reflect an antioxidant capacity of copper [20]. The body's antioxidant barrier is reinforced by the presence of acute phase proteins: e.g. ceruloplasmin, ferritin, and haptoglobin, occurring mainly in the plasma. Their protective action is due to the chelation of metal ions, responsible for the production of free radicals [21]. Oxidative stress occurs when the activity of antioxidant control mechanisms is reduced causing increased ROS generation. Altindag et al. [29] suggest a negative correlation between OSI (oxidative stress index) and BMD in the patients with osteoporosis after menopause. This means that BMD decreases with increasing oxidative stress. The increased activity of osteoclasts and the inhibition of osteoblast activity, in patients with postmenopausal osteoporosis, may be the result of an imbalance in oxidation-antioxidant mechanisms [29].

The relationships between the level of activity of antioxidant enzymes and physical activity have been analyzed. These studies involved patients with shortterm and long-term hypokinesia resulting in impaired physiological and biochemical reactions, leading to degenerative arthritis and bone metabolism disturbances. The data show that limited physical activity can disrupt the balance of oxidation-reduction and stimulate ROS formation. This suggests that increased activity of superoxide dismutase occurs in patients with reduced mobility [22-25]. However, in other studies, hypokinesis was found at low levels of antioxidant enzymes, which influenced pro-antioxidant processes [27-28, 91]. SOD activity can be further enhanced by melatonin supplementation and the activity of catalase-chromium compounds $[25,90]$. Reactive oxygen species begin the process of lipid peroxidation, which results in increased levels of MDA in bones, that is cytotoxic and mutagenic and may contribute to carcinogenesis [26]. The level of MDA is significantly reduced in the patients after hip replacement and forced reduction of physical activity. This demonstrates the functionality of the antioxidant system in inhibiting lipid peroxidation [22-24].

The results reported by various authors [22-25, 27-28, 91-92] are ambiguous. This justifies a reconsideration of the role of antioxidant enzymes in the patients with cardiovascular diseases on bones and joints. This will contribute to a more complete picture of the response of bone tissue to different external stressors. Analyses of the activity of antioxidant enzymes in patients will provide information on the defensive reaction mechanisms during environmental stressors [33]. The pathogenesis of diseases of bones and joints indicates the participation of ROS in the formation and development of osteoporosis, rheumatoid arthritis, and osteoarthritis [22-24, 86-87, 93-94]. Increasing oxidative stress may contribute to the development of diabetic bone disorders [79]. However, the role of the
ROS in the pathogenesis of diseases of bones and joints is still unclear. Examination of the activity of antioxidant enzymes in patients will lead to better diagnosis of these diseases and more appropriate pharmacological interventions that can significantly reduce oxidative stress.

In summary, we analyzed specific relationships between the degrees of accumulation of physiologically different chemical elements in human bone in industrialized areas. This review shows the association between exposure arising from smoking, the effect of amalgam dental fillings, as well as diet and food preferences, and the level of chemical elements, lipoperoxidation and reactions of pro-antioxidative systems in humans. They are important for the patient survey, taking into account possible stress factors (tobacco, alcohol, dental amalgams, diet, disease, hereditary conditions, and occupational and environmental exposure to toxic agents). They show direct relationships between the level of chemical elements in the body and degree of response to external stressors. These analyses make relevant comparisons within groups of external subjects. They indicate the importance of external factors in the development of defense capabilities of the human skeleton. They also play a decisive role in the diagnosis of bone diseases.

\section{Conclusions}

Specific relationships between the degrees of accumulation of physiologically different chemical elements in human bone and the scale of the problem in industrialized areas allows accurate identification of responses from parallel physiological systems. We presented to what extent humans are the link between exposure arising from smoking, the effect of amalgam dental fillings, as well as diet, food preferences, and the level of chemical elements, lipoperoxidation and pro-antioxidative reactions. They are important for the patient, taking into account stress factors. They have direct relationships with the level of chemical elements in the body and affect the degree of response to external factors. These indicate the importance of external factors in the development of defense capabilities of the human skeletal system. They also play a decisive role in the diagnosis of bone diseases.

1. An important factor determining the condition of the human skeletal system in anthropogenic areas is environmental destabilization. The physiology of the osteoarticular system results in undesirable accumulation of toxic elements ( $\mathrm{Pb}, \mathrm{Cd}, \mathrm{Hg}, \mathrm{Ni}, \mathrm{Cr}$, Al) in bones, which may potentially be involved in the pathogenesis of bone diseases.

2. Multiple exposures to harmful external factors may lead to pathological changes in the osteoarticular system. Diseases including osteoporosis, osteo- 
arthritis, rheumatoid arthritis, systemic lupus erythematosus, systemic sclerosis, osteomalacia and gout are influenced by surrounding environment factors such as diet, drugs, low physical activity and occupational exposure to chemicals.

3. Relationships between the antioxidant system and bone condition predict the potential risks in certain diseases of the osteoarticular system and systemic connective tissue diseases and suggest action to reduce oxidative stress. They develop the response of disturbed skeletal system to environmental stressors associated with the impact of toxic ions.

\section{References}

1. Roux S, Brown J. Osteoclast Apoptosis in Rheumatic Diseases Characterized by a High Level of Bone Resorption (Osteoporosis, Rheumatoid Arthritis, Myeloma and Pagets Disease of Bone). Current Rheumatology Reviews. 2009; 5(2): 98-110, doi: 10.2174/157339709788298428.

2. Feng Xu, McDonald JM. Disorders of bone remodeling. Annu Rev Pathol 2011; 6: 121-145, doi: 10.1146/annurev-pathol-011110-130203, indexed in Pubmed: 20936937.

3. Valković V, Jakšić M, Krmpotić-Nemanić J. Distribution of trace elements within bones in nasal cavity and labyrinth in humans. Biol Trace Elem Res. 1987; 12(1): 375-382, doi: 10.1007/BF02796693, indexed in Pubmed: 24254616.

4. Samudralwar DL, Robertson JD. Determination of major and trace elements in bones by simultaneous PIXE/PIGE analysis. Journal of Radioanalytical and Nuclear Chemistry Articles. 1993; 169(1): 259-267, doi: 10.1007/bf02046801

5. Kwapulinski J, Brodziak B, Bogunia M. Relative changes of elements in human osseous tissue. Bull Environ Contam Toxicol. 2003; 70(6): 1089-1096, doi: 10.1007/s00128-003-0094-1, indexed in Pubmed: 12756445

6. Zaichick V, Zaichick S, Karandashev V, et al. The effect of age and gender on $\mathrm{Al}, \mathrm{B}, \mathrm{Ba}, \mathrm{Ca}, \mathrm{Cu}, \mathrm{Fe}, \mathrm{K}, \mathrm{Li}, \mathrm{Mg}, \mathrm{Mn}, \mathrm{Na}, \mathrm{P}, \mathrm{S}, \mathrm{Sr}, \mathrm{V}$, and Zn contents in rib bone of healthy humans. Biol Trace Elem Res. 2009: 129(1-3): 107-115, doi: 10.1007/s12011-008-8302-9, indexed in Pubmed: 19107328.

7. Aras NK, Yilmaz G, Alkan S, et al. Trace elements in human bone determined by neutron activation analysis. Journal of Radioanalytical and Nuclear Chemistry. 1999; 239(1): 79-86, doi: 10.1007/bf02349535.

8. Brodziak-Dopierala B, Kwapulinski J, Kusz D, et al. Interactions between concentrations of chemical elements in human femoral heads. Arch Environ Contam Toxicol. 2009; 57(1): 203-210, doi: 10.1007/s00244-008-9228-0, indexed in Pubmed: 18776997

9. Filip R. 2007. Własności strukturalne i materiałowe tkanki kostnej a ryzyko złamań. Reumatologia 47. ; 3: 154-157.

10. Przepierka-Będzak H. 2007. Wartość badań oceniających gęstość mineralną kości i metabolizm kostny u chorych na zesztywniające zapalenie stawów kręgosłupa w wykrywaniu osteoporozy. Rocz. Pom. Akad. Med. w Szczecinie 53. ; 3: 39-47.

11. Ajduković Z, Dimić A, Stanković S, et al. [Mineral substances in the bone tissue and blood of patients with osteoporosis]. Med Pregl. 2009; 62(9-10): 402-406, indexed in Pubmed: 20391733.

12. Watts NB. Clinical utility of biochemical markers of bone remodeling. Clin Chem. 1999; 45(8 Pt 2): 1359-1368, indexed in Pubmed: 10430819

13. Leidig-Bruckner G, Ziegler R. Diabetes mellitus a risk for osteoporosis? Exp Clin Endocrinol Diabetes. 2001; 109 Suppl 2: S493-S514, doi: 10.1055/s-2001-18605, indexed in Pubmed: 11460594.

14. Parada-Turska J, Majdan M. [The musculoskeletal system in diabetic patients]. Postepy Hig Med Dosw (Online). 2005; 59: 236-244, indexed in Pubmed: 15995589.

15. Chernyshova IV, Drozdov VN, Vinokurova LV, et al. [Disorder of mineral density of the bone tissue in patients with chronic pancreatitis]. Eksp Klin Gastroenterol. 2008(7): 29-32, indexed in Pubmed: 19334441.

16. Ruf KM, Clifford T. Management of chronic kidney disease-mineral bone disorder. Orthopedics. 2010; 33(2): 98-101, doi: 10.3928/0147744720100104-20, indexed in Pubmed: 20187588

17. Hrycaj PZ, Łącki JK. 2002. Od zwyrodnienia do zapalenia - współczesne poglądy na patogenezę choroby zwyrodnieniowej stawów. Nowa Med. ; 2.
18. Sierakowski S. 2002. Choroba zwyrodnieniowa stawów na progu XXI wieku. Nowa Med. ; 2.

19. Ścibior D, Czeczot H. 2006. Katalaza-budowa, właściwości, funkcje. Post Hig Med Dośw. ; 60: 170-180.

20. Kubiak K, Klimczak A, Dziki Ł, et al. [Influence of copper (II) complex on the activity of selected oxidative enzymes]. Pol Merkur Lekarski. 2010; 28(163): 22-25, indexed in Pubmed: 20369718.

21. Augustyniak A, Skrzydlewska E. [Antioxidative abilities during aging] Postepy Hig Med Dosw (Online). 2004; 58: 194-201, indexed in Pubmed: 15077054.

22. Mrowicka M, Galecka E, Miller E, et al. [The influence of degenerative changes on the production of free radicals and the lipid peroxidation at the patients after alloplasty of the hip joint]. Pol Merkur Lekarski. 2008; 25(146): 145-149, indexed in Pubmed: 18942334

23. Mrowicka M, Garncarek P, Bortnik K, et al. [Activity of superoxide dismutase (CuZn-SOD) in erythrocytes of patients after hips alloplasty]. Pol Merkur Lekarski. 2008; 24(143): 396-398, indexed in Pubmed: 18634380

24. Mrowicka M, Garncarek P, Gałecka E, et al. 2008c. Activity of catalase and glutathine peroxidase in erythrocytes of patients after hips alloplastic. Kwart Ortop. ; 2: 227-234.

25. Mrowicka M, Garncarek P, Miller E, et al. 2010. Wpływ melatoniny na aktywność dysmutazy ponadtlenkowej (CuZn-SOD) w krwinkach czerwonych chorych w okresie hipokinezji krótko i i długoterminowej. Wiad Lek LXIII. ; 1: 3-9.

26. Gaweł S, Wardas M, Niedworok E, et al. [Malondialdehyde (MDA) as a lipid peroxidation marker]. Wiad Lek. 2004; 57(9-10): 453-455, indexed in Pubmed: 15765761.

27. Kẹdziora J, Buczyński A. 1996. Antioxidative enzymem activites ans lipid peroxidation indicators in blond platelets during bed rest. Int. J. Occup. Med. Environ. Health 9. ; 1: 45-51.

28. Buczyński A, Kowalski W, Pietras R. 1999. Lipid peroxidation and cellular antioxidative systems in the organism subjected to limited motor activity. Przegl Wojsk Med. ; 41: 24-31.

29. Altindag $\mathrm{O}$, Erel $\mathrm{O}$, Soran $\mathrm{N}$, et al. Total oxidative/anti-oxidative status and relation to bone mineral density in osteoporosis. Rheumatol Int. 2008; 28(4): 317-321, doi: 10.1007/s00296-007-0452-0, indexed in Pubmed: 17823800

30. Samborski P, Naskręt D, Araszkiewicz A, et al. Assessment of skin autofluorescence as a marker of advanced glycation end product accumulation in type 1 diabetes. Pol Arch Med Wewn. 2011; 121 (3): 67-72, indexed in Pubmed: 21430607.

31. Traczyk WZ, Trzebski A. red.). 2001. Fizjologia człowieka z elementami fizjologii stosowanej i klinicznej. PZWL, Warszawa. ; 789: pp.

32. Sirola J, Kröger H, Honkanen R, et al. Smoking may impair the bone protective effects of nutritional calcium: a population-based approach. J Bone Miner Res. 2003; 18(6): 1036-1042, doi: 10.1359/jbmr.2003.18.6.1036, indexed in Pubmed: 12817756.

33. Wiśniewska A. 2014. Wpływ pierwiastków chemicznych na układ kostny i enzymatyczną barierę antyoksydacyjną u człowieka. Ph.D. Thesis, CM UMK, Bydgoszcz. ; 200: pp.

34. Głogowska-Szeląg J, Marek B, Nowak M. 2010. Choroba zwyrodnieniowa stawów a preparaty imbiru. Acta Balneol LII. ; 2: 103-106.

35. Kontny E. 2011. Patogeneza reumatoidalnego zapalenia stawów. Część I - odpowiedź nabyta, uwarunkowania genetyczne i środowiskowe. Reumatologia, 49. ; 1: 47-54.

36. Gravallese E, Goldring S. Cellular mechanisms and the role of cytokines in bone erosions in rheumatoid arthritis. Arthritis \& Rheumatism. 2000; 43(10): 2143-2151, doi: 10.1002/1529-0131(200010)43:10<2143::aid-anr1>3.3.co;2-j.

37. Kokot F. ed.) 2004. Choroby wewnetrzne. PZWL, Warszawa. ; 476: pp.

38. Majithia V, Geraci SA. Rheumatoid arthritis: diagnosis and management. Am J Med. 2007; 120(11): 936-939, doi: 10.1016/j.amjmed.2007.04.005, indexed in Pubmed: 17976416.

39. Deal C. Bone loss in rheumatoid arthritis: systemic, periarticular, and focal. Curr Rheumatol Rep. 2012; 14(3): 231-237, doi: 10.1007/s11926012-0253-7, indexed in Pubmed: 22527950.

40. Dobrogowski J, Wordliczek J, Istrati J. 2012. Zespoły bólowe narządu ruchu. Bóle kręgosłupa Wyd PZWL. : Warszawa.

41. Dega W, Senger A, Król J. 1996. Ortopedia i rehabilitacja. Wyd. PZWL, Warszawa. ; 575: pp.

42. Malemud CJ, Islam N, Haqqi TM. Pathophysiological mechanisms in osteoarthritis lead to novel therapeutic strategies. Cells Tissues Organs. 2003; 174(1-2): 34-48, doi: 10.1159/000070573, indexed in Pubmed: 12784040

43. Buckwalter J, Saltzman C, Brown T. The Impact of Osteoarthritis. Clinical Orthopaedics and Related Research. 2004; 427: S6-S15, doi: 10.1097/01.blo.0000143938.30681.9d.

44. Lis K, Odrowąż-Sypniewska G, Nowacki W. 2005. Ocena stężenia IGF-1 w surowicy krwi i płynie stawowym u kobiet ze zmianami zwyrod- 
nieniowymi stawu biodrowego o różnej etiologii. Chirurgia Narządów Ruchu Ortop. Pol 70. ; 6: 407.

45. Naylor K, Eastell R. Bone turnover markers: use in osteoporosis. Na Rev Rheumatol. 2012; 8(7): 379-389, doi: 10.1038/nrrheum.2012.86, indexed in Pubmed: 22664836.

46. Genovese M. Treatment of Rheumatoid Arthritis. Kelley's Textbook o Rheumatology. 2009: 1119-1143, doi: 10.1016/b978-1-4160-32854.10067-1.

47. Caracchini G, Cavalli L. Severe osteoporosis: diagnosis of femoral fractures. Clin Cases Miner Bone Metab. 2010; 7(2): 97-101, indexed in Pubmed: 22460012.

48. El Maghraoui A, Borderie D, Cherruau B, et al. Osteoporosis, body composition, and bone turnover in ankylosing spondylitis. J Rheumatol. 1999; 26(10): 2205-2209, indexed in Pubmed: 10529141.

49. Kanis JA, Glüer CC. An update on the diagnosis and assessment of osteoporosis with densitometry. Committee of Scientific Advisors, International Osteoporosis Foundation. Osteoporos Int. 2000; 11(3) 192-202, indexed in Pubmed: 10824234

50. Rabiega D, Woźniak J, Olejniczak T, et al. 2000. Osteoporoza-epidemiologia, patogeneza, diagnostyka i leczenie. Przew Lek. ; 9: 39-46.

51. Geusens P, Lems WF. Osteoimmunology and osteoporosis. Arthritis Res Ther. 2011; 13(5): 242, doi: 10.1186/ar3375, indexed in Pubmed: 21996023

52. Roux C. Osteoporosis in inflammatory joint diseases. Osteoporos Int. 2011; 22(2): 421-433, doi: 10.1007/s00198-010-1319-x, indexed in Pubmed: 20552328.

53. Goldacre MJ, Roberts SE, Yeates D. Mortality after admission to hospital with fractured neck of femur: database study. BMJ. 2002 325(7369): 868-869, indexed in Pubmed: 12386038.

54. Parfitt AM, Qu S, Rao DS. The mineralization index--a new approach to the histomorphometric appraisal of osteomalacia. Bone. 2004; 35(1): 320-325, doi: 10.1016/j.bone.2004.02.016, indexed in Pubmed: 15207773

55. Bhambri R, Naik V, Malhotra N, et al. Changes in bone mineral density following treatment of osteomalacia. J Clin Densitom. 2006 9(1): 120-127, doi: 10.1016/j.jocd.2005.11.001, indexed in Pubmed: 16731441

56. Starek A. 2007. Toksykologia narządowa. PZWL, Warszawa. ; 438: pp.

57. GRAYZEL AI, LIDDLE L, SEEGMILLER JE. Diagnostic significance of hyperuricemia in arthritis. N Engl J Med. 1961; 265: 763-768, doi: 10.1056/NEJM196110192651601, indexed in Pubmed: 13901338.

58. Mandell BF. Clinical manifestations of hyperuricemia and gout. Cleve Clin JMed 2008: 75 Supp 5: S5-S8, indexed in Pubmed: 18822469.

59. Gińdzieńska-Sieśkiewicz E, Sierakowski S, Domysławska I, et al. 2010. Dna moczanowa - aktualne spojrzenie na diagnostykę i leczenie. Reumatologia, 48. ; 6: 425.

60. Majdan M, Borys $\mathrm{O}$. [Gout and comorbidities associated with hyperuricemia]. Ann Acad Med Stetin. 2010; 56 Suppl 1: 34-39, indexed in Pubmed: 21365938.

61. Seifert M, Watkins B. ROLE OF DIETARY LIPID AND ANTIOXIDANTS IN BONE METABOLISM. Nutrition Research. 1997; 17(7): 1209-1228, doi: 10.1016/s0271-5317(97)00090-0.

62. Theppeang K, Glass TA, Bandeen-Roche K, et al. Associations of bone mineral density and lead levels in blood, tibia, and patella in urban-dwelling women. Environ Health Perspect. 2008; 116(6): 784-790, doi: 10.1289/ehp.10977, indexed in Pubmed: 18560535.

63. Alfvén T, Järup L, Elinder CG. Cadmium and lead in blood in relation to low bone mineral density and tubular proteinuria. Environ Health Perspect. 2002; 110(7): 699-702, indexed in Pubmed: 12117647.

64. Patrick L. Toxic metals and antioxidants: Part II. The role of antioxidants in arsenic and cadmium toxicity. Altern Med Rev. 2003; 8(2): 106-128, indexed in Pubmed: 12777158.

65. Akesson A, Bjellerup P, Lundh T, et al. Cadmium-induced effects on bone in a population-based study of women. Environ Health Perspect. 2006: 114(6): 830-834, indexed in Pubmed: 16759980.

66. Nyhäll-Wåhlin BM, Petersson IF, Nilsson JA, et al. BARFOT study group. High disease activity disability burden and smoking predict severe extra-articular manifestations in early rheumatoid arthritis. Rheumatology (Oxford). 2009; 48(4): 416-420, doi: 10.1093/rheumatology/kep004 indexed in Pubmed: 19213849

67. Jakubowski M, Muszer J, Slota P. 1995. The risk of exposure on cadmium in chosen the bronches of industry. Med Pracy, ; 46: 109-122.

68. Czeczot H, Skrzycki M. [Cadmium--element completely unnecessary for the organism]. Postepy Hig Med Dosw (Online). 2010; 64: 38-49, indexed in Pubmed: 20173219.
69. Cuypers A, Plusquin M, Remans T, et al. Cadmium stress: an oxidative challenge. Biometals. 2010; 23(5): 927-940, doi: 10.1007/s10534-0109329-x, indexed in Pubmed: 20361350

70. Moulis JM, Thévenod F. New perspectives in cadmium toxicity: an introduction. Biometals. 2010; 23(5): 763-768, doi: 10.1007/s10534010-9365-6, indexed in Pubmed: 20632201

71. Graczyk A. 1992. Glin - nowa trucizna środowiska. Bibl. Monit. Środ. 999, Warszawa. ; 87: pp.

72. Colbin A. 2000. Osteoporoza. Jak leczyć ją dietą. Wyd. Książka i Wiedza, Warszawa. ; 272: pp.

73. Scala J. 2000. Artretyzm. Jak leczyć go dieta. Książka i Wiedza, Warszawa. : 274: pp.

74. Theodosakis J, Buff S. 2011. Artretyzm: zwyrodnieniowa choroba stawów, reumatoidalne zapalenie stawów: nowe sposoby leczenia. Klub Dla Ciebie, Warszawa. ; 270: pp.

75. Pieleszek A, Stanosz S. 1994. Wpływ dwusiarczku węgla na wysteppowanie przekwitania u kobiet. Med Pracy. ; 45: 383-391.

76. Altzitzoglou T, LaRosa JJ, Nicholl C. Measurement of $90 \mathrm{Sr}$ in bone ash. Appl Radiat Isot. 1998; 49(9-11): 1313-1317, indexed in Pubmed: 9699292.

77. Pilviö R, LaRosa JJ, Mouchel D, et al. Measurement of low-level radioactivity in bone ash. Journal of Environmental Radioactivity. 1999; 43(3): 343-356, doi: 10.1016/s0265-931x(98)00064-2.

78. Rapuri PB, Gallagher JC, Kinyamu HK, et al. Caffeine intake increases the rate of bone loss in elderly women and interacts with vitamin D receptor genotypes. Am J Clin Nutr. 2001; 74(5): 694-700, doi: 10.1093/ajcn/74.5.694, indexed in Pubmed: 11684540

79. Hamada $Y$, Fuiii $H$, Fukagawa M. Role of oxidative stress in diabetic bone disorder. Bone. 2009; 45: S35-S38, doi: 10.1016/j. bone.2009.02.004

80. Barrère F, van Blitterswijk CA, de Groot K. Bone regeneration: molecular and cellular interactions with calcium phosphate ceramics. Int J Nanomedicine. 2006; 1(3): 317-332, indexed in Pubmed: 17717972.

81. Carlens C, Hergens MP, Grunewald J, et al. Smoking, use of moist snuff, and risk of chronic inflammatory diseases. Am J Respir Crit Care Med. 2010; 181(11): 1217-1222, doi: 10.1164/rccm.200909-1338OC, indexed in Pubmed: 20203245

82. Brodziak-Dopierała B, Kwapuliński J Sobczyk K et al. The occurrence of nickel and other elements in tissues of the hip joint. Ecotoxicol Environ Saf. 2011; 74(4): 630-635, doi: 10.1016/j.ecoenv.2010.09.012, indexed in Pubmed: 20932577.

83. Spodaryk K. 2002. Patologia narządu ruchu. PZWL, Warszwa. ; 285: pp.

84. Matyska-Piekarska E, Łuszczewski A, Łacki J, et al. [The role of oxidative stress in the etiopathogenesis of rheumatoid arthritis]. Postepy Hig Med Dosw (Online) 2006: 60: 617-623, indexed in Pubmed: 17199103.

85. Skólmowska M, Kmieć M. [Antioxidant enzymosomes - properties and application]. Postepy Hig Med Dosw (Online). 2011; 65: 640-644, indexed in Pubmed: 22100796.

86. Łuszczewski A, Matyska-Piekarska E, Trefler J, et al. ŚliwińskaStańczyk P. 2007. Reaktywne formy tlenu - znaczenie w fizjologii i stanach patologii organizmu. Reumatologia $45 \cdot 5 \cdot 284-289$.

87. Fitowska A, Ostałowska A, Dobrakowski M, et al. Protein metabolism in the synovial membrane in the hip osteoarthritis. Pol Orthop Traumatol. 2012; 77: 21-26, indexed in Pubmed: 23306282

88. Gacko M, Worowska A, Karwowska A, et al. 2006. Extracellular Superoxide Dismutase in Vascular Wall. Adv Clin Exp Med 15. ; 5: 925-932.

89. Valko M, Leibfritz $D$, Moncol J et al. Free radicals and antioxidants in normal physiological functions and human disease. Int J Biochem Cell Biol. 2007; 39(1): 44-84, doi: 10.1016/j.biocel.2006.07.001, indexed in Pubmed: 16978905.

90. Malinowska K, Modranka R. 2010. Wpływ związków chromonu na aktywność wybranych enzymów antyoksydacyjnych $u$ chorych z ograniczeniami ruchowymi Pol. Merk Lek XXVIII. ; 163: 26-28.

91. Pawlak W, Kedziora J, Zolynski K, et al. Effect of long term bed rest in men on enzymatic antioxidative defence and lipid peroxidation in erythrocytes. J Gravit Physiol. 1998; 5(1): P163-P164, indexed in Pubmed: 11542339.

92. Zaichick V, Zaichick S. Instrumental neutron activation analysis of trace element contents in the rib bone of healthy men. Journal of Radioanalytical and Nuclear Chemistry. 2009: 281(1): 47-52, doi: 10.1007/s10967-009-0084-9

93. Wauquier $F$, Leotoing $L$, Coxam V, et al. Oxidative stress in bone remodelling and disease. Trends Mol Med. 2009; 15(10): 468-477, doi: 10.1016/j.molmed.2009.08.004, indexed in Pubmed: 19811952.

94. Goc S, Błaszczyk J, Ziajka P, et al. Górna1 E., Kowalczyk E. 2011. Wybrane elementy równowagi oksydacyjno-redukcyjnej u pacjentów z chorobą zwyrodnieniową stawów biodrowych. 